\title{
Fuel Poverty and Access to Electricity: Comparing Households When They Differ in Needs*
}

\author{
Paul Makdissi ${ }^{\dagger} \quad$ Quentin Wodon ${ }^{\ddagger}$
}

June 2001

\begin{abstract}
Although sequential stochastic dominance techniques have been used in the literature to make comparisons of income poverty which are robust to the assumptions made about the economies of scale within households, the techniques could be applied to a much wider set of issues. In this paper, we apply the techniques to energy deprivation in Guatemala. We compare fuel poverty among households with and without access to electricity, and we assess whether access to electricity for those who do not have access currently would eliminate the observed difference in fuel poverty between the two groups of households.

Keywords: Energy, electricity, poverty, equivalence scales, sequential stochastic dominance JEL Numbers: I32, Q42

*This paper was funded by a grant from the World Bank's Research Support Budget. The opinions expressed here are those of the authors and need not represent those of the World Bank, its Executive Directors, or the countries they represent. We are grateful to Vivien Foster and Jean-Philippe Tre for comments and discussions on this topic.

† Département d'économique and CEREF, Université de Sherbrooke, 2550 boulevard de l'Université, Sherbrooke, Québec, Canada, J1K 2R1; email: paul.makdissi@courrier.usherb.ca

$\ddagger$ LCSPR, World Bank, 1818 H Street, NW, Washington, DC 20433, USA, Email:
\end{abstract} qwodon@worldbank.org. 


\section{Introduction}

In developing countries, a substantial share of the population is not able to satisfy its basic energy needs. Part of the problem is due to the households' insufficient income to buy the amount of energy they need, and this will typically be captured by the traditional concept of income poverty. But another part of the problem is due to the technologies used by the poor for lighting, heating, and cooking. While electricity tends to be cheaper than other fuels when the higher efficiency of electricity as compared to the other fuels is taken into account, many among the poor do not have access to modern fuels such as electricity. Providing access to electricity could thus reduce the extent of fuel poverty substantially.

In order to assess the impact on fuel poverty of providing better access to electricity, we must first be able to measure fuel poverty, and to compare the level of fuel poverty between those households with and without access (ideally, controlling for other variables determining fuel poverty such as income). This is not straightforward. When comparing deprivation or poverty between groups, an analyst is typically confronted with three difficulties. First, the analyst must identify the households who do not meet their basic needs. In the context of energy or fuel poverty, this can be handled by suggesting a minimum energy consumption threshold and considering as fuel poor those who do not reach the threshold. Yet since there may be a lack of consensus on the appropriate threshold, the analyst may want to test for the robustness of the comparisons to the choice of the threshold. Second, the analyst must aggregate the information on deprivation at the household level to obtain an overall deprivation measure for the population group. This can be done by using an index of deprivation or poverty, such as the headcount index, the poverty gap, or the squared poverty 
gap. However, there are many more indices of poverty which are being used in the literature, and a change from one poverty index to another may lead to different results. Finally, the analyst is confronted to a comparison problem: how to compare the energy consumption of households of different sizes? The usual way of tackling this third problem is to chose an equivalence scale to transform the household energy consumption into an equivalent energy consumption for a household of one person. The equivalence scale usually takes into account two factors. First, a larger household will need more energy than a smaller one to achieve the same level of comfort. Second, there may be large economies of scale in energy consumption within the household. Unfortunately, here as well, the analyst may face a lack of consensus on the appropriate equivalence scale to use, and a change in equivalence scale may well lead to different results or fuel poverty comparisons.

To avoid the two first problems, the analyst may concentrate her attention on orderings rather than cardinal comparisons between groups by using stochastic dominance conditions that are available in the poverty literature (Atkinson (1987), Foster and Shorrocks (1988,a,b and c), Jenkins and Lambert (1997, 1998a and b) and Zheng (1999)). However, since those stochastic dominance condition will be applied to equivalent energy consumption, the appropriate choice for the equivalence scale will still be an issue. The approach in the literature to avoid this third problem is to rely on the sequential stochastic dominance techniques first proposed by Atkinson and Bourguignon (1984) for welfare measurement, and later adapted for poverty measurement by Atkinson (1992). This approach enables the analyst to make comparisons that will be robust to a change of deprivation threshold (poverty line), deprivation index (poverty measure), or equivalence scale. Atkinson's results were extended by Jenkins and Lambert (1993) to allow comparisons of populations with different demographic structures. Chambaz and Maurin (1998) proposed a second degree sequential 
stochastic dominance condition which extends the ranking power of the method at the cost of more stringent measurement assumptions. Finally, Duclos and Makdissi (1999) generalized those results to any order of dominance, each order being associated with measurement assumptions. They also proposed to reverse the way to look at the problem. Instead of making a priori measurement assumptions and then checking if a robust comparison can be made, they search for critical sets of measurement assumptions that are coherent with a given poverty comparison.

In this paper, we use Duclos and Makdissi's method to analyze fuel poverty in Guatemala. As mentioned earlier, considering fuel poverty rather than the more traditional concept of income poverty introduces a whole set of interesting issues regarding the consumption of various fuels by households who may not all have access to the same energy sources, the relative efficiency of the various fuels used by households, and the extent to which households benefits from economies of scale. Section 2 presents our methodology for implementing sequential stochastic dominance tests and for measuring the level of energy consumption of households using different fuels. Section 3 provides our empirical results, where we compare fuel poverty among households with and without access to electricity, and we assess whether access to electricity for those who do not have access currently would suffice to eliminate the observed difference in fuel poverty between the two groups of households. A brief conclusion follows. 


\section{Methodology}

\subsection{Deprivation indices and equivalence scales}

In order to use sequential stochastic dominance techniques for ordinal fuel poverty comparisons between households groups, we must make some minimal assumptions on the structure of energy needs and the deprivation function or poverty index. Let $d_{k}(x)$ represents the energy deprivation of households of $k$ members with an energy consumption of $x$. We assume that this function is non negative for all households and zero for households with energy consumption higher than the deprivation threshold $z_{k}$. We also assume that the deprivation index is additive. This assumption simply means that the total deprivation for a given population is the sum of the deprivation for the households in that population.

In terms of the structure of energy needs, we assume that the energy deprivation thresholds (i.e., the fuel poverty lines) are such that the threshold for households of a given size cannot be higher than the thresholds for larger households. This is easy to accept if we believe that larger households need more energy to achieve the same level of energy comfort than smaller households. More precisely, when making a poverty comparison, we assume that for households of individuals there exists a subset of equivalence scales $\left[1, m_{k}^{+}\right]$under which the fuel poverty comparison holds, with $m_{k}^{+}=z_{k}^{+} / z_{1}^{+}$, where $z_{k}^{+}$and $z_{1}^{+}$are the maximum admissible energy deprivation thresholds for households of size $k$ and one. For example, if there are no economies of scale, the maximum deprivation threshold for households with 3 members is three times the maximum threshold for households of size one, so that $m_{3}^{+}=3=z_{3}^{+} / z_{1}^{+}$. In the empirical work, we will work with 6 different household sizes $1,2,3,4,5$ and 6 or more.

In the poverty literature, it is standard to work with classes of poverty indices. These 
classes are used to impose a structure on the deprivation function $d_{k}(x)$, and they are denoted by $\Delta^{s}, s=1,2,3, \ldots$ where $s$ represents the order of stochastic dominance, each of which has specific normative assumptions which are discussed below. Formally, the assumption we impose on the deprivation functions are:

$$
(-1)^{i} \frac{d^{i} d_{6}(x)}{d x^{i}} \leq(-1)^{i} \frac{d^{i} d_{5}(x)}{d x^{i}} \leq \ldots \leq(-1)^{i} \frac{d^{i} d_{1}(x)}{d x^{i}} \leq 0 \text { for all } i \in\{1,2, \ldots, s\}
$$

For $s=1$, this assumption implies that an increase in household energy consumption $x$ reduces energy deprivation, whatever the household type to which this increased energy consumption accrues. It also says that, for a given level of energy consumption $x$, the potential for such deprivation reduction is greater for households with more members. For $s=2$, the assumption says that the deprivation indices respect the Pigou-Dalton transfer principle which stipulates that a transfer of one unit of energy to a deprived household from a less deprived household decreases fuel poverty, and this effect is again stronger for households of a larger size. While in practice it is unlikely that actual energy consumption units will be transferred from some households to others as is the case for income through taxation and redistribution, it is easy to imagine policies such as changes in prices which will affect households with low and high levels of energy consumption differently in part because they do not use the same sources of energy. For $s=3$, the indices are sensitive to favorable composite transfers and this sensitivity is again higher for larger households. Composite transfers are such that a favorable Pigou-Dalton transfer within the lower part of the distribution, accompanied by a reverse Pigou-Dalton transfer within the higher part reduces poverty if the variance of the distribution has not increased. This normative principle has been introduced by Kolm (1976) into the inequality measurement literature, and adapted by Kakwani (1980) to poverty measurement. A normative interpretation of $s>3$ can be given using Fishburn and Willig's (1984) generalized transfer principle, still recalling that 
for every order $s$, our assumptions imply that the reduction in poverty will be greater for larger households.

\subsection{Sequential stochastic dominance}

In order to present the logic of sequential stochastic dominance conditions, we must introduce the concept of C-Curves where $\mathrm{C}$ stands for cumulative. Let $F_{E k}(x)$ be the cumulative distribution of energy consumption $x$ for households of $k$ individuals with access to electricity. The distribution is defined over an interval $[0, a] . F_{N k}(x)$ is defined analogously for households of $k$ individuals without access to electricity. Let $\theta_{E k}$ represent subgroup $k$ 's population share among household with electricity. If $D_{E k}^{1}(x)=F_{E k}(x)$ and $D_{E k}^{s}(x)=\int_{0}^{x} D_{E k}^{s-1}(x) d x$, for all integer $s=2,3, \ldots$, Duclos and Makdissi (2000) show that deprivation will be lower for households with electricity than for those without for all deprivation indices belonging to the class $\Delta^{s}$ if and only if the following condition is respected:

$$
C_{E k}^{s}(x) \leq C_{N k}^{s}(x) \text { for all } x \leq z_{k}^{+} \text {, for all } k=1 \text { to } 6
$$

with $C_{E k}^{s}(x)=\sum_{l=k}^{6} \theta_{E l} D_{E l}^{s}(x)$ and $C_{N k}^{s}(x)$ defined analogously. Although this condition may seem complex, it is easy to test empirically because it involves only checking for non intersection of the C-Curves $C_{E k}^{s}(x)$ and $C_{N k}^{s}(x)$ up to a given maximum deprivation threshold $z_{k}^{+}$which is specific to each household size. An analyst can say with confidence that there is less fuel poverty among households with access to electricity than among households without access if and only if for all household sizes, $C_{E k}^{s}(x)$ lies everywhere under $C_{N k}^{s}(x)$ up to the maximum admissible energy deprivation thresholds $z_{k}^{+}$.

This condition is depicted in Figure 1, where we consider only two different household

sizes, 1 and 2. We must check first if $C_{E 2}^{s}(x)$ lies everywhere under $C_{N 2}^{s}(x)$ up to the maximum deprivation threshold $z_{2}^{+}$and then check if $C_{E 1}^{s}(x)$ lies everywhere under $C_{N k}^{s}(x)$ 
up to the maximum deprivation threshold $z_{1}^{+}$. In this hypothetical example with households of only two sizes, $C_{E 2}^{1}(x)$ and $C_{N 2}^{1}(x)$ represent respectively the cumulative distributions of energy consumption for two persons households who have and do not have access to electricity. Since $C_{N 2}^{1}(x)$ lies everywhere above $C_{E 2}^{1}(x)$ up to $z_{2}^{+}$, we can say that among two persons households, those without access to electricity are more likely to be fuel poor than those with access up to the maximum admissible fuel poverty line for households of two persons. Next, $C_{E 1}^{1}(x)$ and $C_{N 1}^{1}(x)$ represent the cumulative distributions of energy consumption for the entire population with and without access to electricity. Each of these two curves is the weighted sum of the cumulative distributions of energy consumption for two persons households and for singles in the respective samples (with and without access to electricity). The weigths are the population shares by household size. In a more general case, $C_{E k}^{1}(x)$ and $C_{N k}^{1}(x)$ would represent the weighted sums of the cumulative distributions of energy consumption for households larger than $k$. In the example in Figure $1, C_{N 2}^{1}(x)$ lies again above $C_{E 2}^{1}(x)$ up to $z_{1}^{+}$. The fact that the two C-curves for those without access to electricity lie above the curves for those with access implies that there is fuel poverty dominance of those with access versus those without access, and that this dominance is robust to the assumptions made regarding the energy needs of households of different sizes.

If the test of first order sequential stochastic dominance has failed (i.e., if the C-curves intersect), we cannot infer a robust deprivation ordering over the specified set of deprivation indices and deprivation threshold upper bounds $z_{k}^{+}$. To find a robust deprivation ordering, we have three options. The first option consists in increasing the order of stochastic dominance until a deprivation ordering becomes robust over all of the pre-specified ranges of deprivation thresholds. By doing this, we are working on the aggregation dimension of the poverty comparison problem by restricting the set of admissible deprivation indices. The 
second option infers for a given order s critical bounds for restricted intervals of deprivation thresholds for single persons while maintaining the initial ranges for the ratios of $z_{k}^{+} / z_{1}^{+}$ which correspond to the assumptions for the equivalence scales. By restricting the interval of deprivation thresholds, we are working on the identification problem mentioned in the introduction. As a third option, we can work on the comparison problem for households with different needs by changing the ratios $z_{k}^{+} / z_{1}^{+}$(and thereby the admissible equivalence scales) so that a deprivation ordering becomes robust for a given upper bound energy threshold $z_{1}^{+}$ for single people and for a pre-specified order of stochastic dominance $s$.

In the empirical work, in order to implement the three options outlined above, the key step consists in finding the lowest values of $\sigma_{k}^{s}, k=1,2, . ., 6$, for which the C-curves intersect. This gives us a set of upper deprivation threshold bounds that may or may not obey the assumptions made on the rankings of the deprivation thresholds for different household sizes. To ensure that $z_{k}^{+} \leq z_{k+1}^{+}$, we proceed by iteration, first defining $z_{6}^{s}=\sigma_{6}^{s}$, and then setting the remaining $z_{k}^{s}$ as $z_{k}^{s}=\min \left(\sigma_{k}^{s}, z_{k+1}^{s}\right)$, for $k=1,2, \ldots, 5$. Interpreting $z_{1}^{s}$ as the robust upper bound for the deprivation threshold of a single person, we use the estimated vector $z^{s}=\left(z_{1}^{s}, z_{2}^{s}, \ldots, z_{6}^{s}\right)$ to estimate the sets of equivalence scales for which a deprivation ordering is robust at order $s$. The critical set of equivalence scales is given by $m(k) \in\left[1, \min \left(k, z_{k}^{s} / z_{1}^{s}\right)\right]$. Note that if $z_{1}^{+}$is the maximum deprivation threshold for single people, the robust set of equivalence scales can be extended using $\left[1, \min \left(k, z_{k}^{s} / z_{1}^{+}\right)\right]$instead of $\left[1, \min \left(k, z_{k}^{s} / z_{1}^{s}\right)\right]$ if $z_{1}^{+}<z_{1}^{s}$.

\subsection{Energy consumption}

In order to make comparisons of fuel poverty or energy deprivation, we first need to define energy consumption $x$. Following Foster et al. (2001), we take into account the quality or 
efficiency of various fuels in so doing. Using the 1998/99 Encuesta Nacional de Ingresos $y$ Gastos Familiares for Guatemala, we convert monthly household expenditures for batteries, candles, electricity, fuelwood, kerosene and butane gas into units of efficient energy as follows. Denoting by $P_{i j}$ the price paid by household $i$ per kilowatt-hour of energy obtained from fuel $j$ with $j=1,2, \ldots, J$, by $E_{i j}$ the household expenditures for that fuel, by $E F_{j}$ the efficiency factor reflecting the quality of one kilowatt-hour of fuel $j$, and by $X_{i j}$ the amount of energy provided by fuel $j$ in standardized efficient kilowatt-hours, we compute the total amount of efficient energy consumed by household $i, X_{i}$, as follows:

$$
X_{i}=\sum_{j=1}^{J} X_{i j}=\sum_{j=1}^{J} \frac{C_{i j}}{P_{i j} / E F_{j}}
$$

If we were not taking into account each fuel's efficiency factor, we would compute a gross level of energy consumption $G_{i}$ which would not adequately represent the energy comfort of households:

$$
G_{i}=\sum_{j=1}^{J} G_{i j}=\sum_{j=1}^{J} \frac{C_{i j}}{P_{i j}}
$$

The efficiency factors $E F_{j}$ are expressed in relative terms, with the efficiency of each fuel compared to that of electricity. Because electricity is the most efficient fuel at the household level, all efficiency factors are below one. This implies that for each household, $G_{i}$ is larger than $X_{i}$. In the empirical section, we will compare the results of fuel poverty comparisons made with both $G_{i}$ and $E_{i}$ in order to show the importance of taking efficiency factors into account. Additionally, we will simulate the impact of providing access to electricity to those households who do not currently have access. To do so, we will use a result from Foster et al. (2001) suggesting that access to electricity reduces the average price paid by households per efficient kilowatt-hour of energy by 27.7 percent. This estimate was obtained by regressing the logarithm of the price paid per efficient kilowatt-hour against a large number of independent variables including access to electricity. Assuming that after 
getting access to electricity, the households who do not currently have access keep their expenditures for energy constant, a reduction in the price per efficient kilowatt-hour of 27.7 percent translates into an increase in energy consumption of the same amount. Using the techniques of sequential stochastic dominance, we will compare the new simulated level of efficient energy consumption for the households previously without access to electricity to the actual level of consumption of the households with access today in order to test whether providing access alone would eliminate the differences in fuel poverty observed between the two groups.

\section{Empirical Results}

Table 1 provides a few summary statistics for the households with and without access to electricity. On average, households with access to electricity have a higher level of efficient energy consumption than households without access. But households without access tend to have a larger level of gross energy consumption than households with access, which underscores the lower quality of the fuels they use, in large part due to their lack of access to electricity. Figures 2 and 3 provide the density functions for, respectively, the gross and efficient energy consumption of the two groups of households.

In Table 2, we use sequential stochastic dominance to compare fuel poverty among households with and without access to electricity using gross energy consumption as our measure of energy consumption. Despite the fact that on Figure 2, households without access seem to have higher levels of gross energy consumption than households with access, we find restricted dominance of households with access over households without access, although for very low thresholds (this corresponds roughly in Figure 2 to the left part of the Figure where the density function for households with access is below that for households without access). 
The first column of Table 2 provides the values $\sigma_{k}^{s}$ under which $C_{M k}^{s}(x)$ lies under $C_{N k}^{s}(x)$ for $s=1$. The other columns provide the values for higher orders of dominance. To find the highest gross energy deprivation threshold per person for which households with access dominate households without access at any given order of dominance, we must divide the values provided in Table 2 by the number of households in the corresponding groups. If we consider all additive poverty measures for $s=1$ and all equivalence scales in $[0, k]$, we must restrict the deprivation threshold for a single person to lie between 0 and $419(=2518 / 6)$ gross kwh per year, since the binding $\sigma_{k}^{s}$ is for households of 6 or more individuals. This is very low (the mean gross energy consumption for the two groups of households in Table 1 is above $12,500 \mathrm{kwh}$ ), so that for practical purposes, we can say that there is no dominance.

Table 3, which deals with net energy consumption, provides a very different picture. Here, households with access to electricity dominate households without access for $s>1$. For $s=1$, without restriction on the equivalence scales, the dominance of households with access remains as long as the deprivation threshold for a single person lies between 0 and 5, 026 efficient kilowatt-hour per year $(=10052 / 2)$, since the binding $\sigma_{k}^{s}$ is for households of 2 members. This is a high level of efficient energy consumption. As discussed in Foster et al. (2001), a reasonable fuel deprivation threshold would be around 2, $150 \mathrm{kwh}$ per year per household in Guatemala. This corresponds to the efficient energy consumption of households whose total expenditures are close to the income poverty line. It also corresponds to what local experts assimilate as basic energy needs, namely the capacity for households to run two 60 watt light bulbs and one 16 watt radio for four hours each day, and to use five two-kilogram logs of fuelwood each day for cooking. In other words, when the appropriate measure of energy consumption is used to assess whether households meet their energy needs, we find that households with access to electricity dominate households without access. 
What would happen if access to electricity were granted to all households? Would this enable the households currently without access to catch up with the households with access? As mentioned in section 2, Foster et al. (2001) estimate that access to electricity reduces the price paid per efficient kwh of energy by 27.7 percent. If households currently without access gain access, and maintain their level of expenditures to its current level, this would translate in an increase of efficient energy consumption of 27.7 percent for these households, but it would not be sufficient to catch up with the households currently with access. As shown in Table 4, there would still be restricted dominance of the households currently with access over the other group. This time however, for $s=1$, the deprivation threshold for a single person would have to lie below 1,568 efficient kwh per year $(=4704 / 3)$, since the binding $\sigma_{k}^{s}$ is for households of 3 members. While this is below the fuel poverty threshold of 2, $150 \mathrm{kwh}$ suggested above, it assumes that there may be no economies of scale in energy consumption, which is not realistic.

If we agree to restrict the set of admissible equivalence scales, and if for the sake of the argument, we consider all energy deprivation thresholds between 0 and $2150 \mathrm{kwh}$ per year, then Table 5 tells us that the highest equivalence scale that we could use would be set by households with two members, with the upper bound 1.80 being equal to $3874 / 2150$. To interpret this maximum, we can use $m(n)=n^{\varepsilon}$, which is the equivalence scale suggested for income in Buhmann et al. (1988). In this formula, $\varepsilon$ is the elasticity of the equivalence scale with respect to the number of members in the household. If $\varepsilon$ is equal zero, energy consumption is a public good within the household. At the other extreme, if $\varepsilon$ is equal to one, there are no economies of scale in energy consumption. For $s=1$, and for energy deprivation thresholds for one individual between 0 and $2150 \mathrm{kwh}$ per year, $\varepsilon$ must lie between 0 and 0.85 (since $2^{0.85}=1.80$ ). For income poverty measurement, many equivalence scales used 
in applied work are lower (e.g., the OECD parametric equivalence scale $\varepsilon$ is 0.5 ). Since it is reasonable to assume that economies of scale are larger for energy consumption than for income poverty, the values suggested in Table 5 imply that it remains reasonable to assume dominance of households with access to electricity over households without access, even if it were feasible to provide access to all the households currently without access. Thus, while providing access to households without access would help in reducing the differences in fuel poverty between these households and the households currently with access, it would not be sufficient to eliminate these differences.

\section{Conclusion}

Using recent advances in sequential stochastic dominance techniques, we have compared in this paper the extent to which households without access to electricity are more likely to be fuel poor than households with access to electricity. While simple comparisons of fuel poverty based on the use of gross energy consumption suggest no dominance for all practical purposes, comparisons taking into account the relative efficiency of the various fuels used by households clearly suggest that households with access to electricity are better off. Because electricity tends to be cheaper than other fuels per unit of efficient energy consumption generated for households, providing universal access to electricity would go some way towards reducing fuel poverty among the households currently without access. Yet this would not be sufficient in and by itself to enable these households to catch up with the households currently with access. This is because apart from access to electricity, other factors affect the ability of households to meet their energy needs, including income which is typically higher among households with access. 


\section{REFERENCES}

Atkinson, A.B. (1987), On the Measurement of Poverty, Econometrica, 55, 759-764.

Atkinson, A.B. (1992), Measuring Poverty and Differences in Family Composition, Economica, 59, 1-16.

Atkinson, A.B. and F. Bourguignon (1987), Income Distribution and Differences in Needs, in G.R. Feiwel (ed.), Arrow and the Foundations of the Theory of Economic Policy, Macmillan, New York.

Buhmann, B., L. Rainwater, G. Schmaus and T.M. Smeeding (1988), Equivalence Scales, Well-Being, Inequality and Poverty: Sensitivity Estimates Across Ten Countries Using the Luxembourg Income Study (LIS) Database, Review of Income and Wealth, $34,115-42$.

Chambaz, C. and E. Maurin (1998), Atkinson and Bourguignon Dominance Criteria: Extended and Applied to the Measurement of Poverty in France, Review of Income and Wealth, 44, 77-124.

Duclos, J.-Y. and P. Makdissi (1999), Sequential Stochastic Dominance and the Robustness of Poverty Orderings, Working Paper 9905, Department of Economics, Université Laval.

ESMAP (1994), Ecuador: Energy Pricing, Poverty and Social Mitigation, Report No. 12831-EC, Energy Sector Management Assistance Program.

Fishburn, P.C. and R.D. Willig (1984), Tranfer Principles in Income Redistribution, Journal of Public Economics, 25, 323-328.

Foster, J.E. and A.F. Shorrocks (1988a), Poverty Orderings and Welfare Dominance, Social Choice and Welfare, 5, 179-198.

Foster, J.E. and A.F. Shorrocks (1988b), Poverty Orderings, Econometrica, 56, 173-177.

Foster, V., J.-P. Tre and Q. Wodon (2001), Energy Prices, Energy Efficiency, and Fuel Poverty, Mimeo, World Bank, Washington DC.

Jenkins, S.P. and P.J. Lambert (1993), Ranking Income Distributions When Needs Differ, Review of Income and Wealth, 39, 337-356.

Jenkins, S.P. and P.J. Lambert (1997), Three 'I's of Poverty Curves, With an Analysis of UK Poverty Trends, Oxford Economic Papers, 49, 317-327.

Jenkins, S.P. and P.J. Lambert (1998a), Ranking Poverty Gap Distributions: Further TIPs for Poverty Analysis, Research on Economic Inequality, 8, 31-38.

Jenkins, S.P. and P.J. Lambert (1998b), Three 'I's of Poverty Curves and Poverty Dominance: TIPs for Poverty Analysis, Research on Economic Inequality, 8, 39-56.

Kakwani, N. (1980), On a Class of Poverty Measures, Econometrica, 48, 437-446.

Kolm, S.C. (1976), Unequal Inequlity: I, Journal of Economic Theory, 12, 416-442. 
Zheng, B. (1999), On the Power of Poverty Orderings, Social Choice and Welfare, 3, 349-371. 
Table 1: Energy consumption per year for households with and without access to electricity

\begin{tabular}{l|c|c}
\hline & $\begin{array}{c}\text { Households with } \\
\text { access to electricity }\end{array}$ & $\begin{array}{c}\text { Households without } \\
\text { access to electricity }\end{array}$ \\
\hline Mean gross consumption $(\mathrm{kwh}) G_{i}$ & 12682 & 18535 \\
Mean efficient consumption $(\mathrm{kwh}) E_{i}$ & 3804 & 2892 \\
\hline
\end{tabular}

Source: Authors' estimation using ENIGFAM 1998/99 for Guatemala.

Table 2: Critical $\mathrm{z}_{\mathbf{k}}{ }^{\mathrm{s}}$ for gross energy consumption (households with access dominate)

\begin{tabular}{l|cccc}
\hline & $\mathrm{s}=1$ & $\mathrm{~s}=2$ & $\mathrm{~s}=3$ & $\mathrm{~s}=4$ \\
\hline $\mathrm{Z}_{1}{ }^{\mathrm{s}}$ & 879 & 2194 & 2903 & 3663 \\
$\mathrm{Z}_{2}{ }^{\mathrm{s}}$ & 917 & 2258 & 2959 & 3710 \\
$\mathrm{Z}_{3}{ }^{\mathrm{s}}$ & 1998 & 2960 & 3562 & 4488 \\
$\mathrm{Z}_{4}{ }^{\mathrm{s}}$ & 2160 & 3080 & 4143 & 5279 \\
$\mathrm{Z}_{5}{ }^{\mathrm{s}}$ & 2329 & 3252 & 4403 & 5656 \\
$\mathrm{Z}_{6}{ }^{\mathrm{s}}$ & 2518 & 3642 & 5108 & 6709 \\
\hline
\end{tabular}

Source: Authors' estimation using ENIGFAM 1998/99 for Guatemala.

Table 3: Critical $\mathrm{z}_{\mathrm{k}}{ }^{\mathrm{s}}$ for efficient energy consumption (households with access dominate)

\begin{tabular}{l|cccc}
\hline & $\mathrm{s}=1$ & $\mathrm{~s}=2$ & $\mathrm{~s}=3$ & $\mathrm{~s}=4$ \\
\hline $\mathrm{Z}_{1}^{\mathrm{s}}$ & 10193 & - & - & - \\
$\mathrm{Z}_{2}^{\mathrm{s}}$ & 10052 & - & - & - \\
$\mathrm{Z}_{3}^{\mathrm{s}}$ & - & - & - & - \\
$\mathrm{Z}_{4}{ }^{\mathrm{s}}$ & - & - & - & - \\
$\mathrm{Z}_{5}^{\mathrm{s}}$ & - & - & - & - \\
$\mathrm{Z}_{6}{ }^{\mathrm{s}}$ & - & - & - & - \\
\hline
\end{tabular}

Source: Authors' estimation using ENIGFAM 1998/99 for Guatemala.

Table 4: Critical $z_{k}{ }^{s}$ for efficient energy consumption under universal access to electricity (households previously with access still dominate)

\begin{tabular}{l|cccc}
\hline & $\mathrm{s}=1$ & $\mathrm{~S}=2$ & $\mathrm{~s}=3$ & $\mathrm{~s}=4$ \\
\hline $\mathrm{Z}_{1}{ }^{\mathrm{s}}$ & 3888 & 35397 & - & - \\
$\mathrm{Z}_{2}{ }^{\mathrm{s}}$ & 3874 & 23719 & - & - \\
$\mathrm{Z}_{3}{ }^{\mathrm{s}}$ & 4704 & - & - & - \\
$\mathrm{Z}_{4}{ }^{\mathrm{s}}$ & - & - & - & - \\
$\mathrm{Z}_{5}{ }^{\mathrm{s}}$ & - & - & - & - \\
$\mathrm{Z}_{6}{ }^{\mathrm{s}}$ & - & - & - & - \\
\hline
\end{tabular}

Source: Authors' estimation using ENIGFAM 1998/99 for Guatemala.

Table 5: Admissible equivalence scales for thresholds below $2150 \mathrm{kwh}$ per year under universal access (equivalence scales for which households previously with access still dominate)

\begin{tabular}{l|cccc}
\hline & $\mathrm{s}=1$ & $\mathrm{~S}=2$ & $\mathrm{~s}=3$ & $\mathrm{~s}=4$ \\
\hline $\mathrm{m}(2)$ & {$[1,1.80]$} & {$[1,2]$} & {$[1,2]$} & {$[1,2]$} \\
$\mathrm{m}(3)$ & {$[1,1.80]$} & {$[1,3]$} & {$[1,3]$} & {$[1,3]$} \\
$\mathrm{m}(4)$ & {$[1,1.80]$} & {$[1,4]$} & {$[1,4]$} & {$[1,4]$} \\
$\mathrm{m}(5)$ & {$[1,1.80]$} & {$[1,5]$} & {$[1,5]$} & {$[1,5]$} \\
$\mathrm{m}(6)$ & {$[1,1.80]$} & {$[1,6]$} & {$[1,6]$} & {$[1,6]$} \\
\hline
\end{tabular}

Source: Authors' estimates using March 1999 EHPHM. 


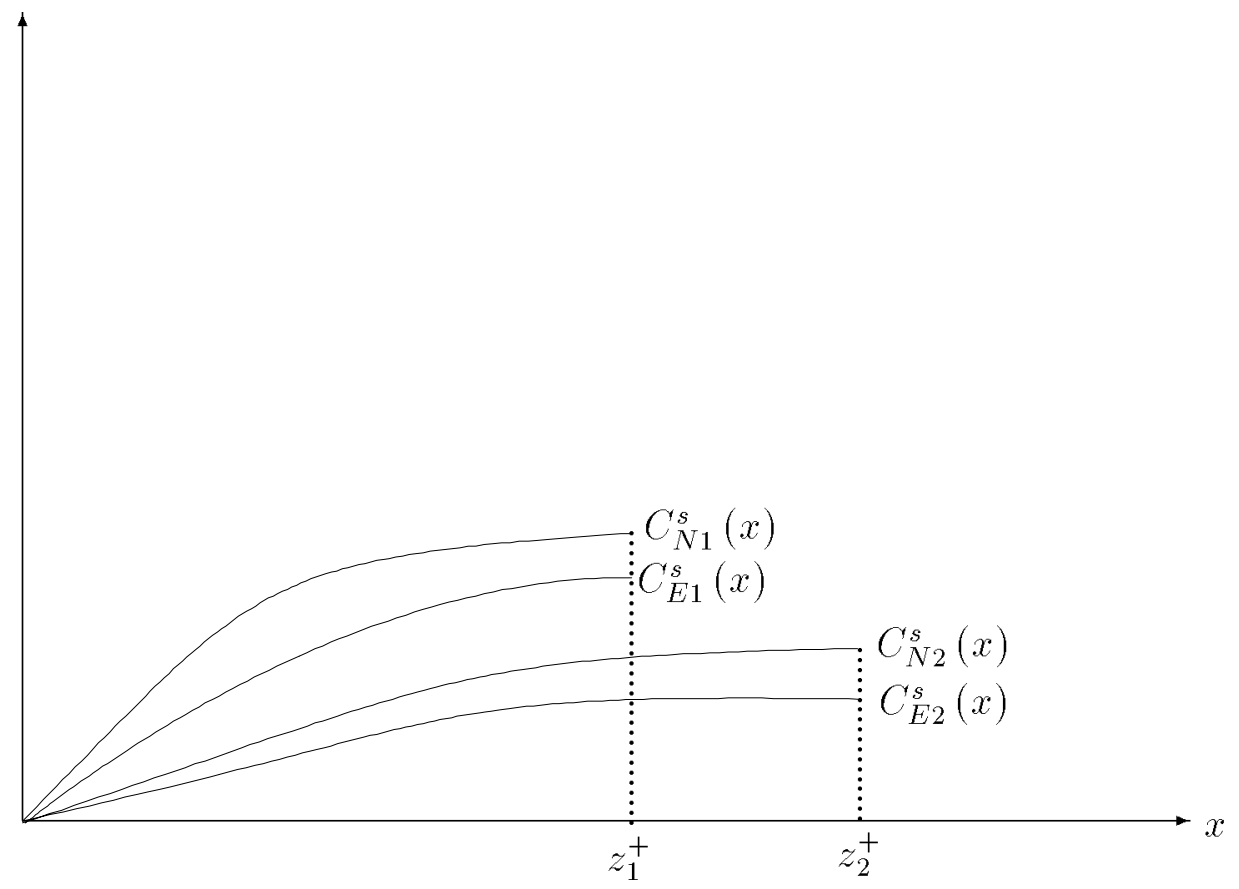

Figure 1: Sequential Dominance Test 
Figure 2: Density function for gross energy consumption

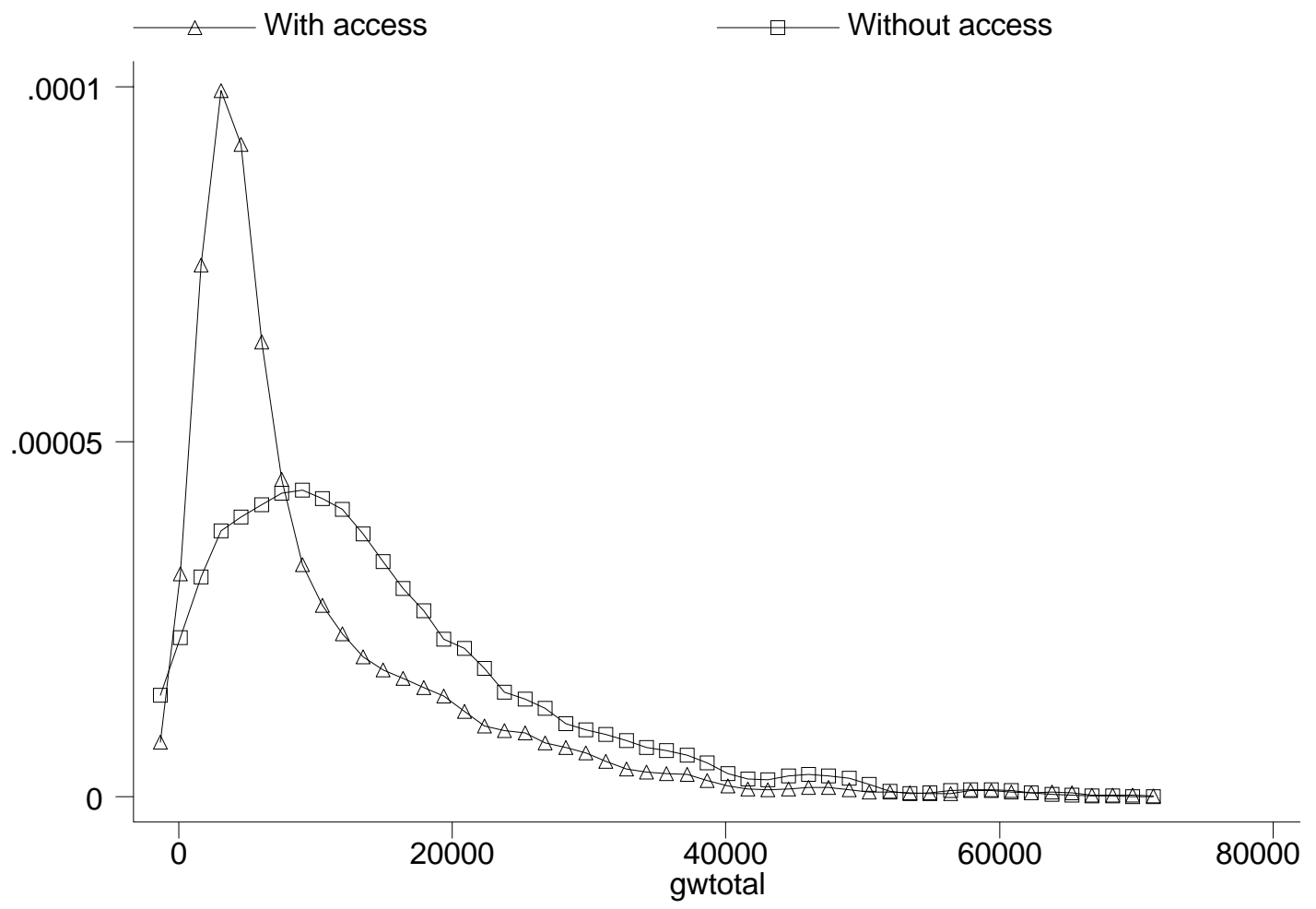

Figure 3: Density function for efficient energy consumption

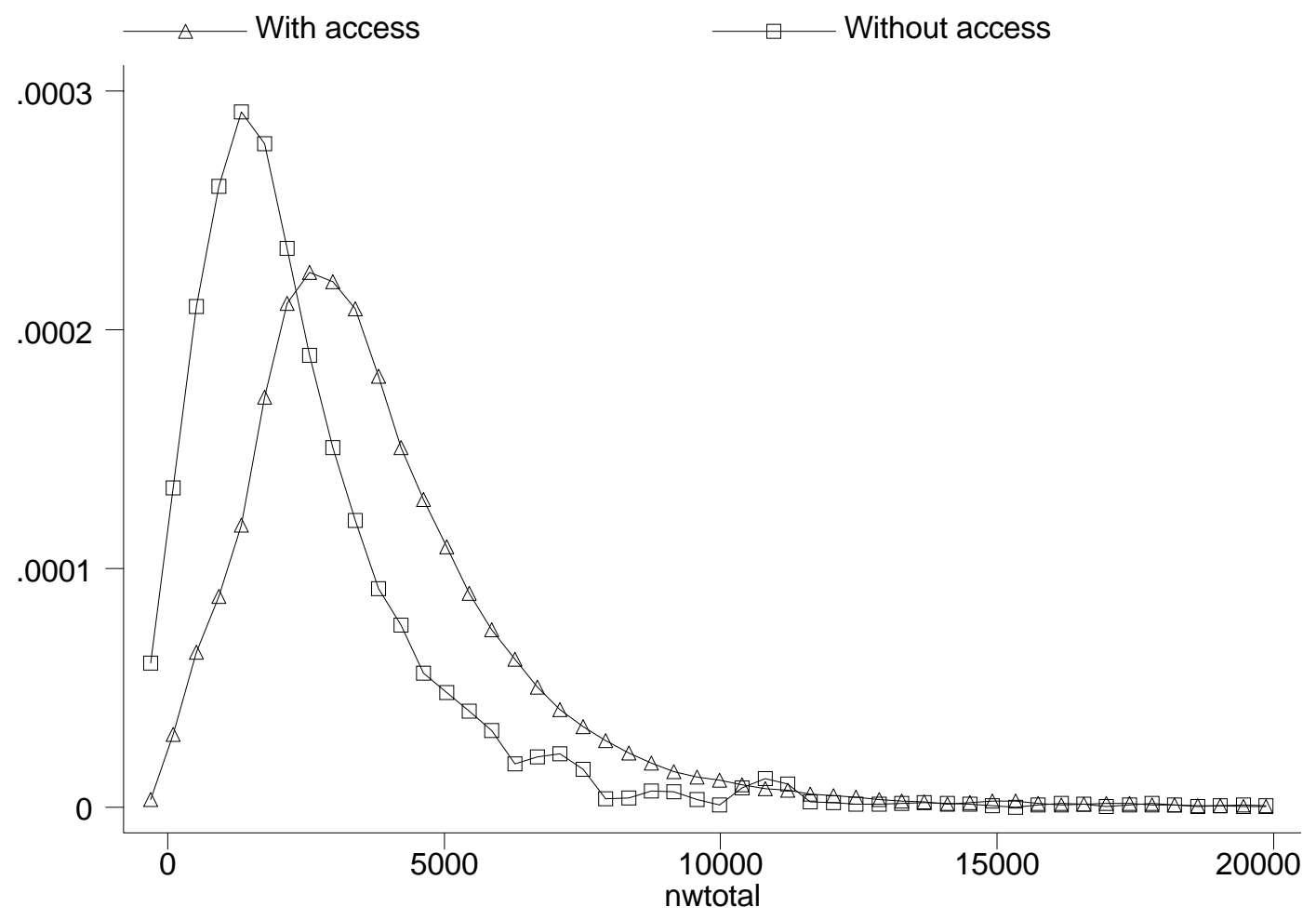


91-01 HANEL, Petr, Standards in International Trade. A Canadian Perspective. (Paru dans Revue Canadienne des Sciences de l'Administration - Canadian Journal of Administrative Sciences, vol. 10.1, Mars 1993).

91-02 FORTIN, Mario, La réforme de l'impôt sur le revenu des particuliers: A-t-on vraiment abaissé les taux d'imposition?

91-03 ASCAH, Louis, Attribution of Pension Fund Surpluses: An Economic Perspective. (Published by Canadian Centre for Policy Alternatives, Ottawa).

91-04 ASCAH, Louis, Attribution du surplus d'un régime de retraite - un regard économique. (Publié par Centre canadien de recherche en politiques de rechange, Ottawa).

91-05 ASCAH, Louis, Recent Federal and Provincial Private Pension Plan Reform Legislation: Missing, Misleading and Shrinking Proposals (Published by Canadian Centre for Policy Alternatives, Ottawa). ASCAH, Louis, La comptabilité des déficits publics : des illusions à la réalité. ALLIE, E., R. DAUPHIN et M. FORTIN, Les aspirations de fertilité des étudiants de l'Université de Sherbrooke. HANEL, PETR, The Liberalization of International Trade in Czechoslovakia, Hungary, and Poland. (Paru dans Comparative Economic Studies, vol. 34, no 3-4, Fall-Winter 1992. ASCAH, Louis, Public Pension Theory for the Real World. FORTIN, Mario, L'écart des taux de chômage canadien et américain. BILODEAU, Marc et AI SLIVINSKI, Rational Nonprofit Entrepreneurship. FORTIN, Mario, The Impact of Unemployment Insurance on the Unemployment Rate. GENTZOGLANIS, Anastassios, Innovation and Competition in the High - and Medium - Intensity R\&D Industries.

93-05 FORTIN, Mario et A. ABDELKRIM, Sectoral Shifts, Stock Market Dispersion and Unemployment in Canada. (Paru dans Applied Economics, volume 29, pp. 829-839, juin 1997.)

93-06 HANEL, Petr, Interindustry Flows of Technology: An Analysis of the Canadian Patent Matrix and Input-Output Matrix for 1978-1989. (Paru dans Technovation, vol 14, no. 8, October 1994.

94-01 BILODEAU, Marc et AI SLIVINSKI, Toilet Cleaning and Department Chairing: Volunteering a Public Service. (À paraître dans Journal of Public Economics)

94-02 ASCAH, Louis, Recent Retirement Income System Reform: Employer Plans, Public Plans and Tax Assisted Savings.

94-03 BILODEAU, M. et AI SLIVINSKI, Volunteering Nonprofit Entrepreneurial Services. (À paraître dans $\underline{\text { Journal of }}$ Economic Behavior and Organization)

94-04 HANEL, Petr, R\&D, Inter-Industry and International Spillovers of Technology and the Total Factor Productivity Growth of Manufacturing Industries in Canada, 1974-1989.

94-05 KALULUMIA, Pene et Denis BOLDUC, Generalized Mixed Estimator for Nonlinear Models: A Maximum Likelihood Approach.

95-01 FORTIN, Mario et Patrice Langevin, L'efficacité du marché boursier face à la politique monétaire.

95-02 HANEL, Petr et Patrice Kayembe YATSHIBI, Analyse de la performance à exporter des industries manufacturières du Québec 1988.

95-03 HANEL, Petr, The Czech Republic: Evolution and Structure of Foreign Trade in Industrial Goods in the Transition Period, 1989-1994. (Paru dans The Vienna Institute Monthly Report, numéro 7, juillet 1995)

95-04 KALULUMIA, Pene et Bernard DÉCALUWÉ, Surévaluation, ajustement et compétitivité externe : le cas des pays membres de la zone franc CFA.

95-05 LATULIPPE, Jean-Guy, Accès aux marchés des pays en développement.

96-01 ST-PIERRE, Alain et Petr HANEL, Les effets directs et indirects de l'activité de R\&D sur la profitabilité de la firme.

96-02 KALULUMIA, Pene et Alain MBAYA LUKUSA, Impact of budget deficits and international capital flows on money demand: Evidence From Cointegration and Error-Correction Model. 

Study Of Selected Countries In Sub-Saharan Africa.

96-04 PARENT, Daniel, Survol des contributions théoriques et empiriques liées au capital humain (A Survey of Theoretical and Empirical Contributions to Human Capital). (Paru dans L'Actualité économique, volume 72. numéro 3, 1996)

96-05 PARENT, Daniel, Matching Human Capital and the Covariance Structure of Earnings

96-06 PARENT, Daniel, Wages and Mobility : The Impact of Employer-Provided Training. (À paraître dans le Journal of Labor Economics)

97-01 PARENT, Daniel, Industry-Specific Capital and the Wage Profile : Evidence From the NLSY and the PSID.

97-02 PARENT, Daniel, Methods of Pay and Earnings: A Longitudinal Analysis

97-03 PARENT, Daniel, Job Characteristics and the Form of Compensation.

97-04 FORTIN, Mario et Michel BERGERON, Jocelyn DUFORT et Pene KALULUMIA, Measuring The Impact of Swaps on the Interest Rate Risk of Financial Intermediaries Using Accounting Data.

97-05 FORTIN, Mario, André LECLERC et Claude THIVIERGE, Testing For Scale and Scope Effects in Cooperative Banks: The Case of Les Caisses populaires et d'économie Desjardins.

97-06 HANEL, Petr, The Pros and Cons of Central and Eastern Europe Joining the EU

00-01 MAKDISSI, Paul et Jean-Yves DUCLOS, Restricted and Unrestricted Dominance Welfare, Inequality and Poverty Orderings

00-02 HANEL, Petr, John BALDWIN et David SABOURIN, Les déterminants des activités d'innovation dans les entreprises de fabrication canadiennes : le rôle des droits de propriété intellectuelle

00-03 KALULUMIA, Pene, Government Debt, Interest Rates and International Capital Flows: Evidence From Cointegration

00-04 MAKDISSI, Paul et Cyril TÉJÉDO, Problèmes d'appariement et politique de l'emploi

00-05 MAKDISSI, Paul et Quentin WODON, Consumption Dominance Curves: Testing for the Impact of Tax Reforms on Poverty

00-06 FORTIN, Mario et André LECLERC, Demographic Changes and Real Housing Prices in Canada.

00-07 HANEL, Petr et Sofiene ZORGATI, Technology Spillovers and Trade: Empirical Evidence for the G7 Industrial Countries.

01-01 MAKDISSI, Paul et Quentin WODON, Migration, poverty, and housing: welfare comparisons using sequential stochastic dominance. Avril 2001. (23 p)

01-02 HUNG Nguyen Manh et Paul MAKDISSI, Infantile mortality and fertility decisions in a stochastic environment. Mars 2001. (12 p).

01-03 MAKDISSI, Paul et Quentin WODON, Fuel poverty and access to electricity: comparing households when they differ in needs Juin 2001. (19 p)

01-04 MAKDISSI, Paul et Yves GROLEAU, Que pouvons-nous apprendre des profils de pauvreté canadiens ? Juillet 2001. (47 p)

01-05 MAKDISSI, Paul et Quentin WODON, Measuring poverty reduction and targeting performance under multiple government programs Août 2001. (16 p)

01-06 DUCLOS, Jean-Yves et Paul MAKDISSI, Restricted inequality and relative poverty. Août 2001. (31 p)

01-07 TÉJÉDO, Cyril et Michel TRUCHON, Serial cost sharing in multidimensional contexts Septembre 2001. (37 p)

01-08 TÉJÉDO, Cyril, Strategic analysis of the serial cost sharing rule with symmetric cost function. Février 2001. $(25 \mathrm{p})$

02-01 DUCLOS, Jean-Yves, Paul MAKDISSI et Quentin WODON, Socially-efficient tax reforms Janvier 2002. (47p)

* Tous ces cahiers de recherche sont disponibles sur notre site WEB (www.usherb.ca/flsh/eco) ou au Centre de documentation de la FLSH A3-330 (UdeS).

Prière d'adresser vos commentaires ou demandes d'exemplaires d'un cahier de recherche antérieur (1976 à 1990) à monsieur Pene KALULUMIA, coordonnateur des Cahiers de recherche du Département d'économique, Tél : 819) 821-7233 Télécopieur : 819) 8217237 Courriel :pkalulum@courrier.usherb.ca

Comments or requests for copies of previous Working Papers (1976 to 1990) should be made to the Working Papers Coordinator at the Département d'économique, Mr. Pene KALULUMIA. Tel: (819) 821-7233

FAX:819) 821-7237 E-mail: pkalulum@courrier.usherb.ca 